\title{
Systematic Review and Meta-Analysis
}

Pre-Implant Surgery

\section{Efficacy of stem cells in maxillary sinus floor augmentation: systematic review and meta-analysis}

\begin{abstract}
T. C. Niño-Sandoval, B. C. Vasconcelos, S. L. D. Moraes, C. A. A. Lemos, E. P. Pellizzer: Efficacy of stem cells in maxillary sinus floor augmentation: systematic review and meta-analysis. Int. J. Oral Maxillofac. Surg. 2018; xxx: xxx-xxx. (c) 2018 International Association of Oral and Maxillofacial Surgeons. Published by Elsevier Ltd. All rights reserved.
\end{abstract}

Abstract. The aim of this review was to test the hypothesis of no difference in the efficacy of bone regeneration when using stem cells in maxillary sinus floor augmentation surgery in comparison to other grafts. Nine randomized clinical trials and one follow-up study involving human subjects were identified through a search of the PubMed/MEDLINE, Scopus, Cochrane, and Web of Science databases, supplemented by a hand search. No significant difference between groups was found for the implant survival rate, increase in bone height, marginal bone loss following implant placement, or new bone formation. With regard to the residual bone graft, an effect favouring the graft group at 3-4 months $(P=0.001)$ and favouring the stem cell group at 6 months $(P=0.01)$ was found. Analyses of the subgroup in which the BMAC system extraction method was used in combination with Bio-Oss, revealed no difference in new bone formation; however, the results for residual bone graft at 3 months favoured the control graft (Bio-Oss) $(P=0.01)$, but at 6 months favoured the stem cells (Bio-Oss + BMAC system) $(P=0.01)$. Based on all findings, the use of stem cells does not contribute significantly to greater implant survival rates or the efficacy of bone regeneration following sinus lift procedures.
T. C. Niño-Sandoval ${ }^{1}$,

B. C. Vasconcelos ${ }^{1}$, S. L. D. Moraes ${ }^{2}$, C. A. A. Lemos ${ }^{3}$, E. P. Pellizzer ${ }^{3}$

${ }^{1}$ Department of Oral and Maxillofacial Surgery, University of Pernambuco, Camaragibe, Pernambuco, Brazil;

${ }^{2}$ Department of Prosthodontics, University of Pernambuco, Recife, Pernambuco, Brazil; ${ }^{3}$ Department of Prosthodontics and Dental Materials, Araçatuba Dental School, São Paulo State University - UNESP, Araçatuba, São Paulo, Brazil
Key words: stem cells; sinus augmentation; sinus lift; review.

Accepted for publication 24 April 2018
The posterior region of the maxilla often requires work for the rehabilitation of edentulous patients. The main challenges in this region are low bone density and anatomical limitations due to alveolar resorption following tooth loss and close contact with the maxillary sinus ${ }^{1,2}$. It is essential to consider the recovery of bone volume for rehabilitation in this area. Maxillary sinus floor augmentation (sinus lift) is considered the most appropriate procedure in such cases.
Autogenous grafts are regarded as one of the best materials for the repair of bone defects $^{2-5}$. The most notable characteristics of these grafts have been described widely in the literature, in animal models and in human and in vitro studies ${ }^{3,6}$. The 
osteoinductive, osteoconductive, and osteogenic properties of autogenous grafts have been demonstrated ${ }^{7}$. This material is used to fill the area between the elevated Schneiderian (sinus) membrane and the posterior maxillary bone ridge. While autogenous bone grafts have properties that enhance the quality of hard tissue recovery, morbidity at the donor site as well as the difficulties posed by the technique during the bone preparation process are important undesirable aspects to consider $^{2-4,8}$.

Continual advances have been made in the field of tissue engineering, offering effective options for the resolution of such problems and representing a solution based partially on natural mechanisms of bone growth and development. One such option is the use of stem cells, which contribute to bone regeneration. Moreover, the acquisition of stem cells is often less traumatic than the acquisition of autogenous bone, which leads to a considerable reduction in donor site morbidity $^{2,8-10}$.

Stem cells have pluripotent characteristics and a mesenchymal origin, with the capacity to differentiate into specific tissues, depending on molecular stimuli ${ }^{9,10}$. In the case of sinus lift, the idea is to enhance the bone regeneration process through the differentiation of stem cells into osteogenic cells ${ }^{11}$. This process has demonstrated important bone recovery, as shown in histological and morphometric analyses ${ }^{12-14}$. Studies involving animals have demonstrated a positive response with regard to the effectiveness of bone repair in the maxillary sinus ${ }^{6}$. However, unlike animal studies, research involving humans is scarce and heterogeneous. For this reason, no definitive method of cellular isolation, scaffold, and tissue of origin for mesenchymal stem cell collection have been established as the most effective for maxillary sinus lift procedures.

This situation was observed in recent systematic reviews related to oral surgery $^{5,15}$, in which the absence of a consensus about the use of stem cells associated with bone graft for maxillary sinus floor augmentation is evident. Thus, the aim of the present study was to perform a systematic review and meta-analysis to evaluate the effectiveness of stem cells in the bone repair process following maxillary sinus floor augmentation. The hypothesis considered was that no difference would be found in comparison to other grafts in this procedure with regard to the efficacy of bone regeneration and the implant survival rate.

\section{Materials and methods}

\section{Study design and registry}

This systematic review was conducted in compliance with the recommendations found in the Cochrane Handbook for Systematic Reviews of Interventions $^{16}$ and the Preferred Reporting Items for Systematic Reviews and Meta-Analyses (PRISMA) ${ }^{17}$. The guiding question was "Is the use of grafts with stem cells more efficacious with regard to bone regeneration in maxillary sinus floor augmentation surgery?', This study is registered in the PROSPERO database (number CRD42017064323).

\section{Eligibility criteria}

The search terms were established using the PICO system: P (patient), i.e. patients submitted to maxillary sinus floor augmentation surgery; I (intervention), i.e. the use of graft material with stem cells; $\mathrm{C}$ (comparison), i.e. comparison to the use of graft material without stem cells; and $\mathrm{O}$ (outcomes), i.e. outcomes corresponding to the efficacy of bone regeneration.

The inclusion criteria were randomized clinical trials that demonstrated the use and effectiveness of grafts with stem cells for maxillary sinus floor augmentation procedures in humans, published in the English language, with no restriction imposed regarding the year of publication. Studies involving animals, in vitro studies, ex vivo studies, case series, and reviews were excluded.

\section{Search strategy}

Searches were performed in the PubMed/ MEDLINE, Scopus, Cochrane, and Web of Science databases for articles published up to May 2, 2017 using the following terms: "stem cells and sinus floor augmentation OR stem cells and sinus augmentation OR stem cells and sinus elevation OR stem cells and sinus lift OR stem cells and sinus graft', The titles and abstracts were read by two independent, blinded researchers (T.N.-S. and C. L.) for the pre-selection of potential articles. Divergences of opinion regarding the inclusion or exclusion of a study were resolved by consensus. If necessary, a third researcher (B.V.) was consulted for the final decision.

Hand-searches were also performed in specialized periodicals: British Journal of Oral and Maxillofacial Surgery, International Journal of Oral and Maxillofacial Surgery, Journal of Dentistry, Medicine and Medical Sciences, Journal of Cranio-Maxillo-Facial Surgery, Journal of Oral and Maxillofacial Surgery, and Oral Surgery, Oral Medicine, Oral Pathology, Oral Radiology.

The criteria for the pre-selection of articles through title and abstract reading included the use of mesenchymal stem cells with an osteogenic lineage regardless of their origin, without a control that includes other stem cell methods. A kappa test was used to determine the level of agreement between the researchers regarding the article selection process ${ }^{18}$.

\section{Data collection process}

Based on the first reading of the articles, two evaluation tables were created for the extraction of the data. The first table contained the main identification data, demographic aspects of the sample, and quantitative measurement data (clinical, imaging, and histomorphometric data). The second table contained the qualitative data (materials employed, exclusion criteria, initial bone height, and type of implant) to complement the information in the first table and enable a more in-depth analysis.

\section{Evaluation of risk of bias}

The risk of bias in the randomized clinical trials was evaluated using the tool proposed by Cochrane ${ }^{19}$ and the Review Manager 5.3 software program (The Nordic Cochrane Centre, The Cochrane Collaboration, Copenhagen, Denmark).

\section{Summary measures}

A meta-analysis was performed with the quantitative data obtained from the randomized clinical trials using Review Manager 5.3, considering differences in mean and standard deviation values. The $I^{2}$ statistic was used for the determination of heterogeneity $(25 \%=$ low, $50 \%$ $=$ moderate, and $75 \%=$ high). The inverse variance method was employed to determine the most adequate model for the analysis. A random-effects model was used if heterogeneity was statistically significant $(P<0.10)$ and a fixed-effects model was used if a larger $P$-value was found $^{20}$. The inverse variance method was used for the evaluation of the implant survival rate and the determination of the risk ratio (RR) with a fixed-effects model, considering the dichotomous nature of the data. 


\section{Results}

\section{Selection of studies}

A total of 590 articles were identified: 104 were found in PubMed, 205 were found in Scopus, 235 were found in Web of Science, 12 were found in the Cochrane database, and 34 were found through the hand search. After analysis of the titles and abstracts, 54 articles were pre-selected. Once duplicates had been removed, 20 articles were submitted to full-text analysis.

The kappa coefficient after the selection of titles and abstracts was 0.87 for PubMed/ MEDLINE, 0.87 for Scopus, 0.93 for Web of Science, 1.0 for Cochrane, and 1.0 for the hand search. According to Landis and $\mathrm{Koch}^{18}$, these kappa coefficients demonstrate a high level of agreement.

After the full-text analysis, 10 articles were excluded: one for using stem cells in the control group ${ }^{21}$, one for not presenting quantitative outcome data ${ }^{4}$, seven for being case series $9,12,13,22-25$, and one for being a compilation of four previously published studies $^{26}$. Figure 1 displays the article selection process.

Thus, 10 articles were selected for the qualitative and quantitative analyses: nine randomized clinical trials $2,7,10,11,14,27-30$ and one follow-up study of a randomized clinical trial offering additional information that completed the evaluation table ${ }^{8}$. Of the nine randomized clinical trials selected for review, three had a partial split-mouth de$\operatorname{sign}^{14,28,30}$. In one of these studies, all maxillary sinuses were randomized and a partial split-mouth cross-over design was employed $^{28}$. In the other two studies, the split-mouth design was performed for bilateral treatment and the remaining patients were included in the stem cell group ${ }^{14,30}$. Three studies employed a complete splitmouth design ${ }^{2,27,29}$. Three other studies employed a design in which half of the sinuses were randomly allocated to the control group and half to the stem cell group $^{7,10,11}$. One hundred and thirty-six patients were included in the studies. Their mean age was 56.46 years (range 49.160.8 years). Table 1 displays the number of patients and maxillary sinuses submitted to stem cell treatment and control treatment (graft without stem cells), as well as a description of the clinical cases.

\section{Implant survival rate}

The difference in implant survival rate was not significant when comparing control grafts and grafts with stem cells $(P=0.06$; Risk ratio (RR) of $4.28,(95 \%$ CI 0.95-19.38)) (Fig. 2).

\section{Imaging characteristics}

All studies involved severe bone defects. The initial alveolar height did not surpass $11.6 \mathrm{~mm}$ and most heights were less than $5 \mathrm{~mm}$ (Table 2). The increase in bone height ( $\mathrm{mm}$ ) was evaluated on radiographs at 4-5 months in two studies ${ }^{11,30}$, and no difference was found between the stem cell and control groups $(P=0.57$; mean difference (MD) $-0.38,95 \% \mathrm{CI}-1.68$ to 0.92) (Fig. 3).

Two studies evaluated the increase in bone height using computed tomography at a similar postoperative evaluation time ${ }^{11,28}$. Once again, stem cells were found to have no significant influence on bone gain $\left(\mathrm{cm}^{3}\right)(P=0.24$; MD $0.23,95 \%$ CI -0.15 to 0.62 ) (Fig. 4 ).

Two studies evaluated marginal bone loss following implant placement ${ }^{8,10}$. No significant difference was found between the groups $(P=0.42 ; \mathrm{MD}-0.27,95 \% \mathrm{CI}$ -0.93 to 0.39 ) (Fig. 5).

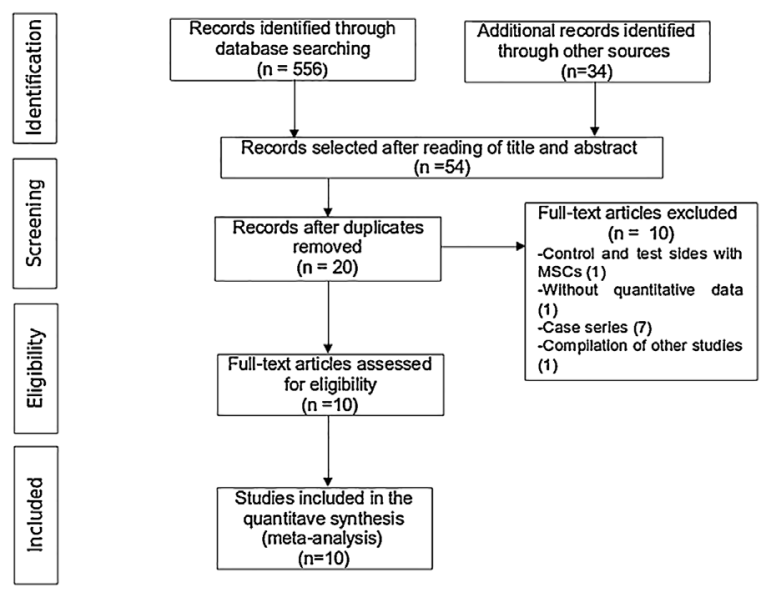

Fig. 1. Article selection process.

\section{Histomorphometric characteristics}

In the majority of randomized clinical trials that involved a histomorphometric analysis, biopsy samples were obtained 3-4 months after maxillary sinus floor augmentation surgery ${ }^{2,14,27-29}$. No significant difference between the stem cell group and the control group (graft without stem cells) was found with regard to the formation of new bone $(P=0.41$; MD $2.21,95 \%$ CI -3.09 to 7.51 ) (Fig. 6A). The same was true for the formation of new bone in samples obtained 6 months after surgery $(P=0.10$; MD $4.29,95 \% \mathrm{CI}$ -0.80 to 9.38 ) (Fig. $6 \mathrm{~B})^{7,27,29,30}$.

As can be observed in Table 2, four studies used the same extraction and cellular isolation method m $^{2,27,28}$, in which BioOss was used as a control and stem cells were isolated with the BMAC method and subsequently were installed in Bio-Oss. This allowed an analysis of subgroups to be performed with regard to new bone formation and residual graft content.

In the subgroup analysis, no significant difference in new bone formation was found between the stem cell group (BioOss + BMAC system) and the control group (Bio-Oss) at 3-4 months $(P=0.86 ; \mathrm{MD}-0.42,95 \% \mathrm{CI}-5.04$ to 4.20) (Fig. 7A). Moreover, no significant difference was found between the stem cell group (Bio-Oss + BMAC system) and the control group (Bio-Oss) at 6 months $(P=0.36 ;$ MD 12.94, 95\% CI -14.72 to 40.60 ) (Fig. $7 \mathrm{~B}$ ).

In studies that determined the influence of treatment on the residual graft, the control group (graft without stem cells) demonstrated better results in comparison to the stem cell group in the evaluations performed at 3-4 months $(P=0.001$; MD 9.96, $95 \%$ CI 3.92 to 16.01 ) (Fig. $8 \mathrm{~A}$ ), whereas a significant difference favouring the stem cell group was found at the 6month evaluation $(P=0.01$; $\mathrm{MD}-5.52$, $95 \% \mathrm{CI}-9.87$ to -1.17 ) (Fig. $8 \mathrm{~B}$ ).

In the subgroup analysis of residual graft content, a difference in favour of the control group (Bio-Oss) was found at 3-4 months $(P=0.01$; MD $8.13,95 \%$ CI 1.73 to 14.52 ) (Fig. 9A). At the 6-month evaluation, the results favoured the stem cell group (Bio-Oss + BMAC system) over Bio-Oss $(P=0.01$; $\mathrm{MD}-8.76$, $95 \% \mathrm{CI}-15.65$ to -1.87 ) (Fig. 9B).

The final histomorphometric measure investigated in this review was the marrow space, which was evaluated in two studies $^{2,28}$. In both studies, the control group was Bio-Oss bovine bone mineral + autogenous graft. As seen in Fig. 10, more marrow space was found in the control 


\begin{tabular}{|c|c|c|c|c|c|c|c|c|c|c|c|}
\hline Author & Patients & Sinuses $^{\mathrm{a}}$ & $\begin{array}{l}\text { Follow-up } \\
\text { after surgery }\end{array}$ & $\begin{array}{l}\text { New bone } \\
\text { formation } \\
\text { (mean, \%) }\end{array}$ & $\begin{array}{l}\text { Presence/residual } \\
\text { graft content } \\
\text { (biomaterial) } \\
(\%)\end{array}$ & $\begin{array}{l}\text { Marrow } \\
\text { space }\end{array}$ & $\begin{array}{l}\text { Increase in } \\
\text { bone height } \\
\text { (mean, mm) }\end{array}$ & $\begin{array}{l}\text { Increase } \\
\text { in bone } \\
\left(\text { mean, } \mathrm{cm}^{3}\right)\end{array}$ & $\begin{array}{l}\text { Bone loss } \\
\text { after implant } \\
\text { placement } \\
(\text { mean, mm) }\end{array}$ & $\begin{array}{l}\text { Healing time } \\
\text { (months) }\end{array}$ & $\begin{array}{l}\text { Implant } \\
\text { survival rate }\end{array}$ \\
\hline $\begin{array}{l}\text { Gonshor } \\
\text { et al. } 2011^{14}\end{array}$ & 14 & $\begin{array}{l}7 \text { BIL }(7 \mathrm{~T}, 7 \mathrm{C}) \\
7 \mathrm{UNI}(7 \mathrm{~T}) \\
\text { Total: } 21 \\
(14 \mathrm{~T}, 7 \mathrm{C})\end{array}$ & 3-4 months & $\begin{array}{l}3-4 \text { months } \\
\text { C: } 18.3 \pm 10.6 \\
\text { T: } 32.5 \pm 6.8\end{array}$ & $\begin{array}{l}\text { 3-4 months } \\
\text { C: } 4.9 \pm 2.4 \\
\text { T: } 25.8 \pm 13.44\end{array}$ & - & - & - & - & T: $3.7 \pm 0.6$ & - \\
\hline $\begin{array}{l}\text { Rickert } \\
\text { et al. } 2011^{2}\end{array}$ & 11 & $\begin{array}{l}11 \text { BIL (11T, } \\
\text { 11C) Total: } 22\end{array}$ & 3-4 months & $\begin{array}{l}3-4 \text { months } \\
\text { C: } 13.08 \pm 6.2 \\
\text { T: } 18.86 \pm 7.36\end{array}$ & $\begin{array}{l}3-4 \text { months } \\
\text { C: } 26.47 \pm 7.3 \\
\text { T: } 28.96 \pm 9.73\end{array}$ & $\begin{array}{l}3-4 \text { months } \\
\text { C: } 54.07 \pm 7.6 \\
\text { T: } 52.4 \pm 5.9\end{array}$ & - & - & - & $\begin{array}{l}3.25-4 \\
(13-16 \text { weeks) }\end{array}$ & - \\
\hline $\begin{array}{l}\text { Rickert } \\
\text { et al. 2014 } \\
\text { (Follow-up } \\
\text { of Rickert } \\
\text { et al. } 2011^{2} \text { ) }\end{array}$ & 12 & $\begin{array}{l}12 \text { BIL (12T, } \\
\text { 12C) Total: } 24\end{array}$ & 12 months & - & - & - & - & - & $\begin{array}{l}12 \text { months } \\
\text { C: } 0.41 \pm 0.25 \\
\text { T: } 0.47 \pm 0.31\end{array}$ & - & $\begin{array}{l}\text { C: } 100 \% \\
\text { T: } 91 \%\end{array}$ \\
\hline $\begin{array}{l}\text { Sauerbier } \\
\text { et al. } 2011^{28}\end{array}$ & 26 & $\begin{array}{l}7 \text { UNI }(6 \mathrm{~T}, 1 \mathrm{C}) \\
9 \text { BIL (18T) } \\
10 \text { BIL (10T, } \\
10 \mathrm{C}) \\
\text { Total: } 45 \\
(34 \mathrm{~T}, 11 \mathrm{C})\end{array}$ & 3-4 months & $\begin{array}{l}3-4 \text { months } \\
\text { C: } 14.3 \pm 1.8 \\
\text { T: } 12.6 \pm 1.7\end{array}$ & $\begin{array}{l}3-4 \text { months } \\
\text { C: } 19.3 \pm 2.5 \\
\text { T: } 31.3 \pm 2.7\end{array}$ & $\begin{array}{l}3-4 \text { months } \\
\text { C: } 57.7 \pm 2.3 \\
\text { T: } 54.4 \pm 2.2\end{array}$ & - & $\begin{array}{l}3-4 \text { months } \\
\text { C: } 1.33 \pm 0.62 \\
(11 \text { samples) } \\
\text { T: } 1.74 \pm 0.69 \\
\text { (28 samples) }\end{array}$ & - & $\begin{array}{l}\text { Total: } \\
3.41 \pm 0.39 \\
\text { C: } 3.34 \pm 0.42 \\
\text { T: } 3.46 \pm 0.43\end{array}$ & - \\
\hline $\begin{array}{l}\text { Hermund } \\
\text { et al. } 2012^{10}\end{array}$ & 19 & $\begin{array}{l}19 \text { UNI (9T, } \\
\text { 10C) } \\
\text { Total: } 19\end{array}$ & 2.5 years & - & - & - & - & & $\begin{array}{l}2.5 \text { years } \\
\text { C: } 1.88 \pm 0.37 \\
\text { T: } 1.27 \pm 0.23\end{array}$ & 4 & $\begin{array}{l}\text { C: }(20 / 20) \\
100 \% \\
\text { T: }(15 / 18) \\
83 \%\end{array}$ \\
\hline $\begin{array}{l}\text { Wildburger } \\
\text { et al. } 2013^{27}\end{array}$ & 7 & $\begin{array}{l}7 \text { BIL }(7 \mathrm{~T}, 7 \mathrm{C}) \\
\text { Total: } 14\end{array}$ & 6 months & $\begin{array}{l}3 \text { months } \\
\text { C: } 11.89 \pm 6.24 \\
\text { T: } 7.46 \pm 4.14 \\
6 \text { months } \\
\text { C: } 13.95 \pm 8.57 \\
\text { T: } 13.53 \pm 5.47\end{array}$ & $\begin{array}{l}3 \text { months } \\
\text { C: } 34.99 \pm 11.89 \\
\text { T: } 42.67 \pm 3.57 \\
6 \text { months } \\
\text { C: } 39.51 \pm 9.3 \\
\text { T: } 36.27 \pm 7.87\end{array}$ & - & - & - & - & - & - \\
\hline $\begin{array}{l}\text { Payer et al. } \\
2014^{29}\end{array}$ & 6 & $\begin{array}{l}6 \text { BIL }(6 \mathrm{~T}, 6 \mathrm{C}) \\
\text { Total: } 12\end{array}$ & 6 months & $\begin{array}{l}3 \text { months } \\
\text { C: } 9.45 \pm 4.15 \\
\text { T: } 10.36 \pm 11.83 \\
6 \text { months } \\
\text { C: } 10.41 \pm 5.25 \\
\text { T: } 14.17 \pm 3.59\end{array}$ & $\begin{array}{l}3 \text { months } \\
\text { C: } 16.40 \pm 18.59 \\
\text { T: } 15.06 \pm 12.52 \\
6 \text { months } \\
\text { C: } 20.26 \pm 11.32 \\
\text { T: } 17.89 \pm 9.63\end{array}$ & - & - & - & - & - & (44/44) 100\% \\
\hline $\begin{array}{l}\text { Kaigler } \\
\text { et al. } 2015^{11}\end{array}$ & 23 & $\begin{array}{l}23 \text { UNI (11T, } \\
\text { 12C) } \\
\text { Total: } 23\end{array}$ & 12 months & - & - & - & $\begin{array}{l}4 \text { months } \\
\text { C: } 12.8 \pm 2.8 \\
\text { T: } 12.2 \pm 3.3\end{array}$ & $\begin{array}{l}4 \text { months } \\
\mathrm{C}: 2.1 \pm 0.9 \\
\mathrm{~T}: 1.8 \pm 1.0\end{array}$ & - & - & $\begin{array}{l}\text { C: }(20 / 20) \\
100 \% \\
\text { T: }(18 / 19) \\
94.73 \%\end{array}$ \\
\hline $\begin{array}{l}\text { Pasquali } \\
\text { et al. } 2015^{7}\end{array}$ & 8 & $\begin{array}{l}8 \text { BIL }(8 \mathrm{~T}, 8 \mathrm{C}) \\
\text { Total: } 16\end{array}$ & 6 months & $\begin{array}{l}6 \text { months } \\
\text { C: } 27.30 \pm 5.55 \\
\text { T: } 55.15 \pm 20.91\end{array}$ & $\begin{array}{l}6 \text { months } \\
\text { C: } 22.79 \pm 9.60 \\
\text { T: } 6.32 \pm 12.03\end{array}$ & - & - & - & - & - & - \\
\hline
\end{tabular}




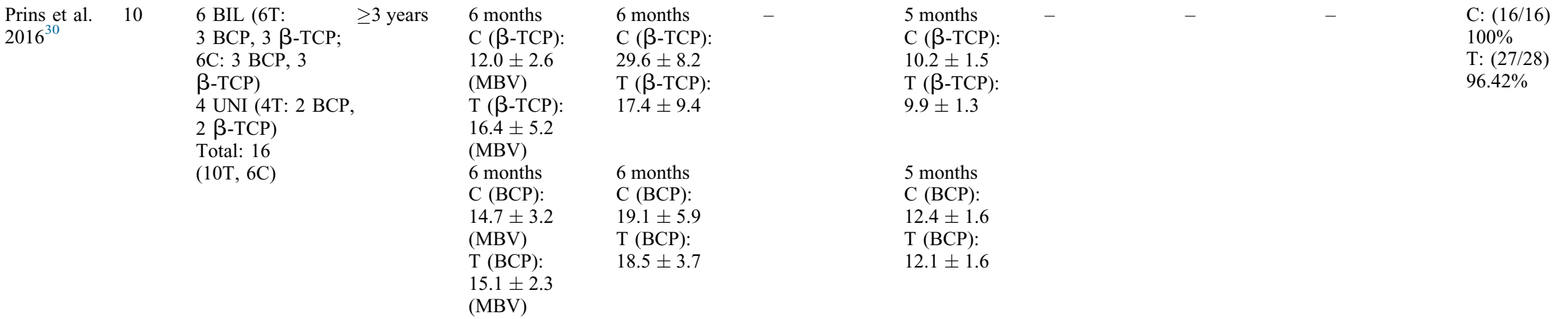

$\mathrm{BCP}$, biphasic calcium phosphate; $\beta$-TCP, beta-tricalcium phosphate; MBV, mineralized bone volume.

${ }^{a}$ BIL, bilateral; UNI, unilateral. 


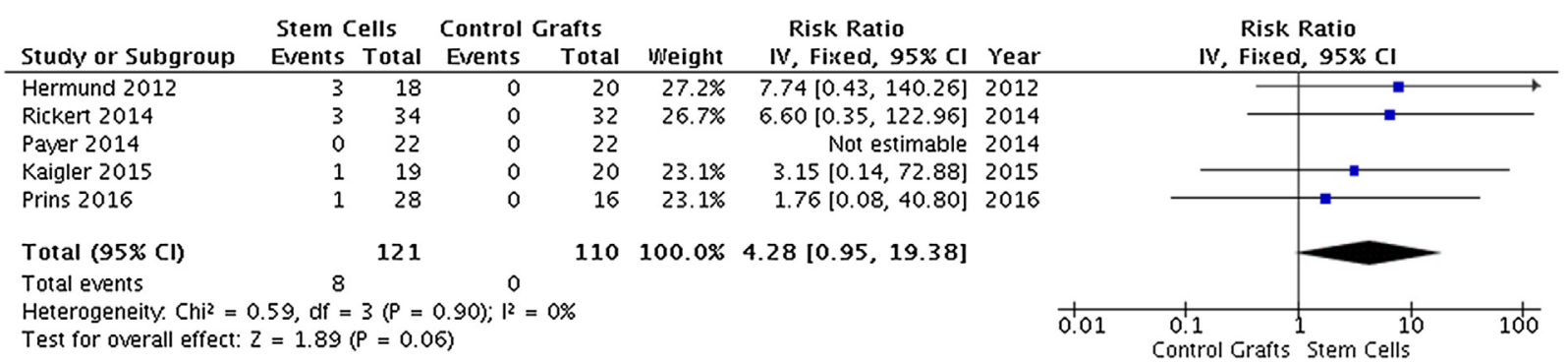

Fig. 2. Implant survival rate: graft vs. graft + stem cells.

group than in the stem cell group $(P<0.0001 ;$ MD $-3.19,95 \%$ CI -4.68 to -1.69$)$.

\section{Assessment of risk of bias}

Figure 11 displays the results of the methodological quality appraisal of the randomized clinical trials.

\section{Discussion}

In this systematic review, the efficacy of bone regeneration was evaluated using histomorphometric aspects (new bone formation, residual graft, and marrow space). No significant difference in the new bone formation rate was found with the use of stem cells in comparison to bone grafts alone for maxillary sinus lift, regardless of the follow-up period. These findings are in disagreement with those of previous reviews, which have reported promising results when stem cells are used in maxillary sinus lift procedures 3,31 . This difference may be explained by the inclusion of only randomized clinical trials in the present review in an attempt to offer better scientific evidence.

Stem cells may be favourable in maxillary sinus lift procedures, as the results for bone regeneration were similar to those achieved with bone grafts, such as BioOss. The literature reports that these materials achieve favourable bone regeneration results that are often similar to the 'gold standard' (autogenous bone) ${ }^{32,33}$.

To reduce as much variation in the results as possible, a subgroup analysis of studies using the same extraction method was considered. The BMAC method combined with Bio-Oss was used in four studies $^{2,7,27,28}$ (Fig. 7). In this analysis, the difference remained non-significant, even though each article showed an important gain in bone formation with stem cells. Considering the absence of a benefit from the use of stem cells, the advantages do not outweigh the disadvantages of performing an extra procedure or the costs needed to associate stem cells with the graft $^{8}$.

Among the studies included in the metaanalysis, Gonshor et al. reported better new bone formation results in the stem cell group in comparison to the control group $^{14}$. This difference may be related to the use of homologous bone in the control group and, to some extent, the use of stem cells contributes to better bone formation compared to bone graft alone. In contrast, higher residual bone graft content was found in the stem cell group in that study, which contributed to the significant difference favouring the control group at the 3-4-month evaluation.

On the other hand, in the analysis of the stem cells obtained using the BMAC method combined with Bio-Oss, the residual bone graft content was significantly lower in the control graft (Bio-Oss) at 3-4 months (Fig. 9A). However, at 6 months, less residual bone graft was found in the stem cell group (Fig. 9B). Similar results were also found for the overall residual graft content (Fig. 8). Thus, it is possible that a healing period of 3-4 months is insufficient to perform the implant installation procedure. Nonetheless this premise can only be proved with the inclusion of new randomized clinical trials.

The final histomorphometric measure investigated in this review was the marrow space, which was evaluated in two studies and was found to be significantly greater in the control group (without stem cells $)^{2,28}$. This finding is important, since this space will be replaced with bone marrow and blood vessels, favouring the blood flow necessary for bone development ${ }^{2,28}$. Both studies reported greater residual bone graft at the 3 -month evaluation, which implies incomplete maturation of the grafts when combined with stem cells in comparison to autogenous bone grafts. This may have been one of the factors contributing to the high implant failure rate in one of the studies evaluat$\mathrm{ed}^{8}$. However, no difference in implant survival rate was found in the comparison of maxillary sinus lift procedures with stem cells and those with bone graft alone. Such results are likely due to the lack of a difference in new bone formation between the two groups.

Another clinical characteristic considered for evaluation in the present review was the healing time, since, in theory, the use of stem cells leads to a shorter healing time and enables earlier implant placement $^{2,4,8,13,14,24,30}$. However, only Sauerbier et al. provided a detailed description of this comparison between the groups ${ }^{28}$. Thus, it was not possible to determine the efficacy of stem cells in terms of this outcome.

Several limitations were found in the present review, one of the most important being the heterogeneity of the materials used and different stem cell sources. In most cases, the stem cells were obtained through an aspiration puncture of the pelvic bone latero-caudally in the upper superior-posterior region of the iliac crest with a bone marrow biopsy nee$\mathrm{dle}^{2,7,11,27,28}$. However, other sources were also used. Payer et al. obtained stem cells from the bone marrow of the medial condyle on the proximal surface of the tibia $^{29}$, although one should consider the possibility that cell concentrations for relevant effects on bone regeneration may be lower in this region in comparison to other sources. Prins et al. obtained adipose tissue cells through liposuction of the abdominal wall ${ }^{30}$. Although such cells have an adequate volume with osteogenic capacity, there are problems regarding the standardization of the process, such as the concentration, due to the fact that the implementation of this technique on humans is relatively recent.

Obtaining stem cells is minimally traumatic for the patient and does not require general anaesthesia or sedation, which is an advantage in relation to aspiration techniques involving the iliac crest, tibial condyle, or abdominal wall. In the study by Hermund et al., cells were obtained from 
Table 2. Qualitative characteristics of studies selected.

\begin{tabular}{|c|c|c|c|c|}
\hline Author & Control graft ${ }^{\mathrm{a}}$ & 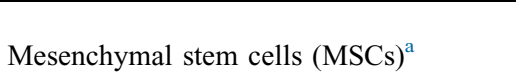 & $\begin{array}{l}\text { Initial alveolar } \\
\text { height, } \mathrm{mm}^{\mathrm{b}}\end{array}$ & Type of implant ${ }^{\mathrm{a}}$ \\
\hline Gonshor et al. $2011^{14}$ & Cancellous particulate allograft (AlloOss) & $\begin{array}{l}\text { Allograft cellular bone graft material } \\
\text { (Osteocel) (from cadavers within } 24 \mathrm{~h} \\
\text { of death) }\end{array}$ & $<5$ & NR \\
\hline Rickert et al. $2011^{2}$ & \multirow{2}{*}{ BBM (Bio-Oss) + autogenous bone } & BBM (Bio-Oss) + iliac crest MSCs: & Left side: & \multirow{2}{*}{$\begin{array}{l}12 \mathrm{~mm} \text { length, } 4.1 \mathrm{~mm} \text { diameter; } \\
\text { endosseous implants (Straumann standard } \\
\text { SLA implants) }\end{array}$} \\
\hline $\begin{array}{l}\text { Rickert et al. } 2014^{8} \\
\text { (follow-up of }\end{array}$ & & $\begin{array}{l}\text { BMAC system (superior-posterior } \\
\text { iliac spine) }\end{array}$ & $\begin{array}{l}2.2 \pm 0.6 \text { Right side: } \\
2.1 \pm 0.3\end{array}$ & \\
\hline Sauerbier et al. $2011^{28}$ & BBM (Bio-Oss) + autogenous bone & $\begin{array}{l}\text { BBM (Bio-Oss) + superior-posterior } \\
\text { iliac spine MSCs: BMAC system }\end{array}$ & $<4$ & NR \\
\hline Hermund et al. $2012^{10}$ & $\begin{array}{l}\text { Composite graft of } 1 \mathrm{~cm}^{3} \text { of autogenous } \\
\text { bone harvested with a scraper } \\
\text { (SafeScraper) from the lateral side of the } \\
\text { maxilla and } 1 \mathrm{~cm}^{3} \text { of DBBM (Bio-Oss) }\end{array}$ & $\begin{array}{l}\text { MSCs (atrophic tuberosity region) } \\
+ \text { composite graft of } 1 \mathrm{~cm}^{3} \text { of } \\
\text { autogenous bone harvested with a scraper } \\
\text { (SafeScraper) from the lateral side of the } \\
\text { maxilla and } 1 \mathrm{~cm}^{3} \text { of DBBM (Bio-Oss) }\end{array}$ & $<3$ & $\begin{array}{l}\text { 10-12 mm length, } 4.1 \text { mm diameter; Wide } \\
\text { Neck/Plus Straumann SLA dental } \\
\text { implants }\end{array}$ \\
\hline Wildburger et al. $2013^{27}$ & BBM (Bio-Oss) & $\begin{array}{l}\text { BBM (Bio-Oss) + BMAC system } \\
\text { (superior-posterior iliac crest) }\end{array}$ & $<3$ & XiVE implants \\
\hline Payer et al. $2014^{29}$ & Bio-Oss $0.25-1 \mathrm{~mm}$ & $\begin{array}{l}\text { Bone marrow (proximal medial tibia } \\
\text { condyle) }+ \text { Bio-Oss } 0.25-1 \mathrm{~mm}\end{array}$ & $<3$ & XiVE implants \\
\hline Kaigler et al. $2015^{11}$ & $\beta$-TCP scaffold & $\begin{array}{l}\text { Stem cell therapy (bone marrow from } \\
\text { posterior iliac crest) (Ixmyelocel-T) }+ \\
\beta-T C P \text { scaffold }\end{array}$ & $\begin{array}{l}\text { Control: } 5.0 \\
(2.5-6.2) \text { MSCs: } \\
3.5(2.1-6.1)\end{array}$ & $\begin{array}{l}10-14 \mathrm{~mm} \text { length, } 3.3-4.8 \mathrm{~mm} \text { diameter; } \\
\text { Straumann oral implants }\end{array}$ \\
\hline Pasquali et al. $2015^{7}$ & $\begin{array}{l}\text { Xenogeneic bone from bovine } \\
\text { hydroxyapatite ( } 1-2 \mathrm{~mm} \text { Bio-Oss) }\end{array}$ & $\begin{array}{l}\text { Bio-Oss, BMAC system (superior- } \\
\text { posterior iliac crest) }\end{array}$ & $\leq 4$ & Black-Fix implants \\
\hline \multirow[t]{2}{*}{ Prins et al. $2016^{30}$} & $\mathrm{BCP}$ & $\begin{array}{l}\mathrm{BCP}+\text { autologous adipose-derived SVF } \\
\text { (from abdominal wall) }\end{array}$ & \multirow[t]{2}{*}{$4-8$} & \multirow[t]{2}{*}{$\begin{array}{l}10-12 \mathrm{~mm} \text { length, } 4.1 \mathrm{~mm} \text { diameter, } \\
\text { Straumann dental implants }\end{array}$} \\
\hline & $\beta-\mathrm{TCP}$ & $\begin{array}{l}\beta \text {-TCP }+ \text { autologous adipose-derived } \\
\text { SVF (from abdominal wall) }\end{array}$ & & \\
\hline
\end{tabular}

BBM, bovine bone mineral; BCP, biphasic calcium phosphate; BMAC, Bone Marrow Aspirate Concentrate; $\beta$-TCP, beta-tricalcium phosphate; DBBM, deproteinized bovine bone mineral; NR, not reported; SVF, stromal vascular fraction.

${ }^{a}$ AlloOss (ACE Surgical Supply Co., Inc. Brockton, MA, USA); Osteocel ${ }^{\circledR}$ (NuVasive ${ }^{\circledR}$, Inc. by ACE Surgical Supply Co., Inc. Brockton, MA, USA); Bio-Oss (Geistlich Biomaterials, Wolhusen, Switzerland); BMAC system (Harvest Technologies Corporation, Plymouth, MA, USA); SafeScraper (Meta, Reggio Emilia, Italy); Ixmyelocel-T (Vericel Corporation, Cambridge, MA, USA); Cerasorb (Curasan AG, Germany); Straumann implants (Institut Straumann AG, Basel, Switzerland); XiVE implants (Dentsply-Friadent, Mannheim, Germany); Black-Fix (AS Technology, São José dos Campos, Brazil)

${ }^{\mathrm{b}}$ Data are shown as the mean \pm standard deviation, or median (range). 


\begin{tabular}{|c|c|c|c|c|c|c|c|c|c|c|}
\hline Study or Subgroup & \multicolumn{3}{|c|}{ Stem Cells } & \multicolumn{3}{|c|}{ Control Grafts } & Weight & \multicolumn{2}{|l|}{ Mean Difference } & $\begin{array}{l}\text { Mean Difference } \\
\text { IV, Fixed, } 95 \% \mathrm{CI}\end{array}$ \\
\hline Kaigler 2015 & 12.2 & 3.3 & 11 & 12.8 & 2.8 & 12 & $26.9 \%$ & $-0.60[-3.11,1.91]$ & 2015 & -1 \\
\hline Prins (BCP) 2016 & 12.1 & 1.6 & 5 & 12.4 & 1.6 & 3 & $32.4 \%$ & $-0.30[-2.59,1.99]$ & 2016 & \\
\hline Prins ( $\beta-T C P) 2016$ & 9.9 & 1.3 & 5 & 10.2 & 1.5 & 3 & $40.7 \%$ & $-0.30[-2.34,1.74]$ & 2016 & \\
\hline Total (95\% CI) & & & 21 & & & 18 & $100.0 \%$ & $.38[-1.68,0.92]$ & & \\
\hline \multicolumn{10}{|c|}{$\begin{array}{l}\text { Heterogeneity: } \mathrm{Chi}^{2}=0.04, \mathrm{df}=2(P=0.98): 1^{2}=0 \% \\
\text { Test for overall effect: } Z=0.57(P=0.57)\end{array}$} & $\begin{array}{lllll}1 & 1 & 1 & 1 & 1 \\
-4 & -2 & 0 & 2 & 4 \\
n t \text { trol Grafts } & \text { Stem Cells }\end{array}$ \\
\hline
\end{tabular}

Fig. 3. Postoperative increase in bone height $(\mathrm{mm})$ : graft vs. graft + stem cells.

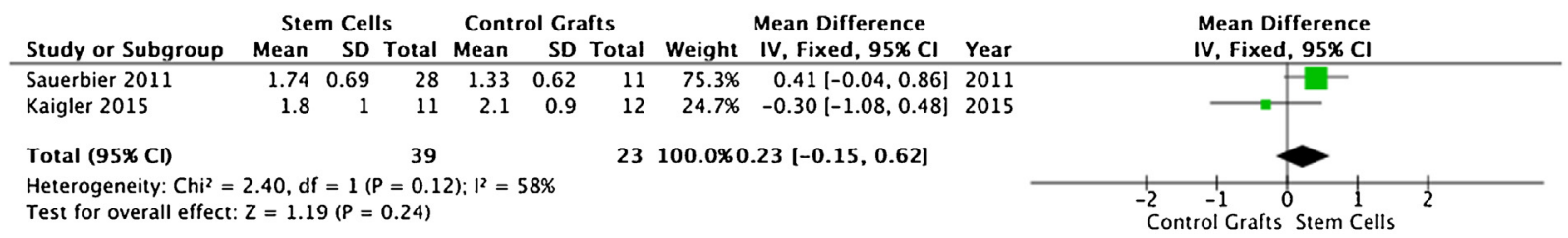

Fig. 4. Postoperative bone volume increase $\left(\mathrm{cm}^{3}\right)$ : graft vs. graft + stem cells.

\begin{tabular}{|c|c|c|c|c|c|c|c|c|c|c|}
\hline \multirow[b]{2}{*}{ Study or Subgroup } & \multicolumn{3}{|c|}{ Stem Cells } & \multicolumn{3}{|c|}{ Control Grafts } & \multirow[b]{2}{*}{ theight } & \multirow{2}{*}{$\begin{array}{l}\text { Mean Difference } \\
\text { IV, Random, 95\% Cl }\end{array}$} & \multicolumn{2}{|r|}{ Mean Difference } \\
\hline & Mean & SD & Total & Mean & SD & Total & & & & IV, Random, 95\% Cl \\
\hline Hermund 2012 & 1.27 & 0.23 & 9 & 1.88 & 0.37 & 10 & $49.3 \%$ & $-0.61[-0.88,-0.34]$ & & 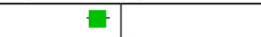 \\
\hline Rickert 2014 & 0.47 & 0.31 & 12 & 0.41 & 0.25 & 12 & $50.7 \%$ & $0.06[-0.17,0.29]$ & & \\
\hline Total (95\% CI) & & & 21 & & & 22 & $100.0 x$ & $-0.27[-0.93,0.39]$ & & \\
\hline $\begin{array}{l}\text { Heterogeneity. } \text { Tau }^{2}= \\
\text { Test for overall effect: }\end{array}$ & $\begin{array}{l}0.21 ; C h i \\
=0.81\end{array}$ & $\begin{array}{l}i^{2}=13 \\
(P=0\end{array}$ & $\begin{array}{l}3.69, \mathrm{df} \\
.42)\end{array}$ & $=1(\mathrm{P}$ & $=0.00$ & $02) ; 1^{2}$ & $=93 \%$ & & -4 & $\begin{array}{ccc}-2 & 1 & 1 \\
\text { Stem Cells Control Graft }\end{array}$ \\
\hline
\end{tabular}

Fig. 5. Marginal bone loss (mm): graft vs. graft + stem cells.

\section{A. New bone formation (3-4 months): Control Grafts Vs. Stem Cells}

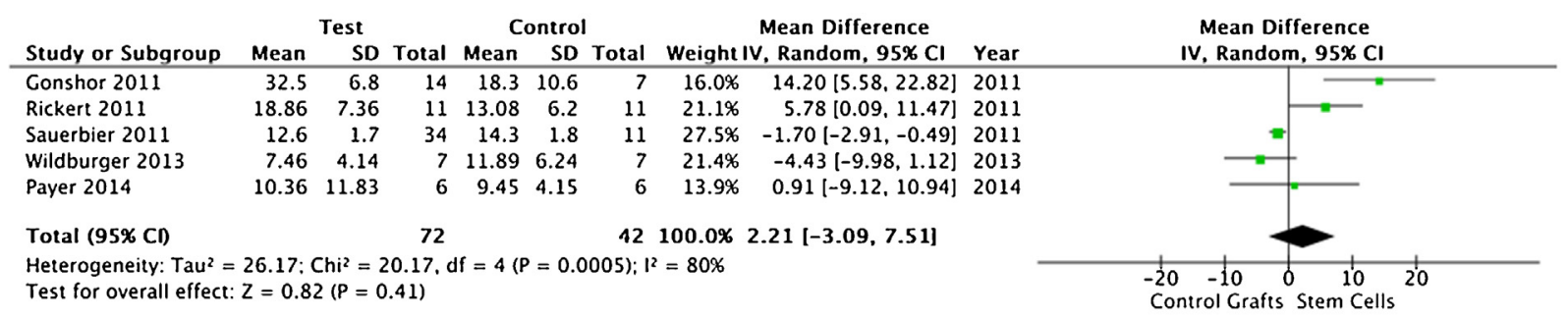

B. New bone formation ( 6 months): Control Grafts Vs. Stem Cells

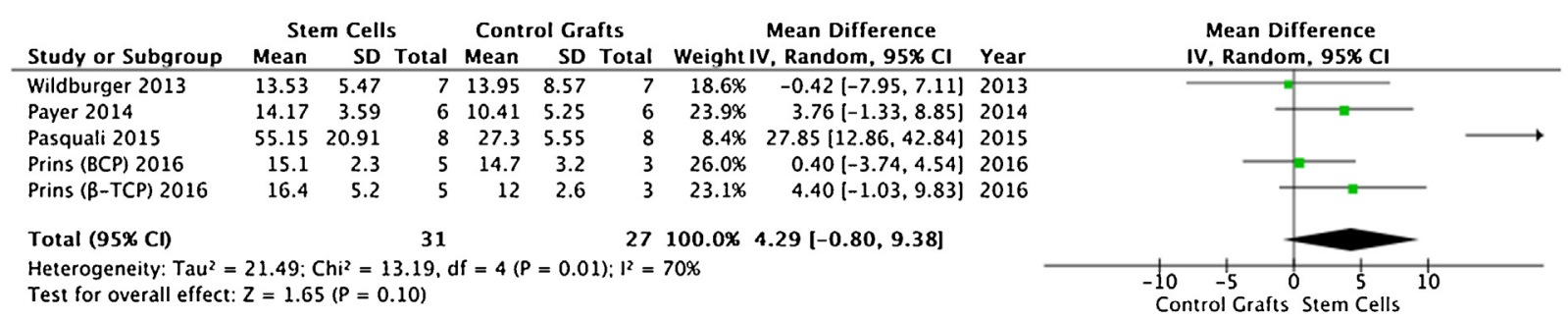

Fig. 6. Overall new bone formation (\%): graft vs. graft + stem cells. (A) At 3-4 months. (B) At 6 months. 
A. New Bone formation (3-4 months): BioOss $®$ Vs. Stem Cells (BioOss $®+$ BMAC system)

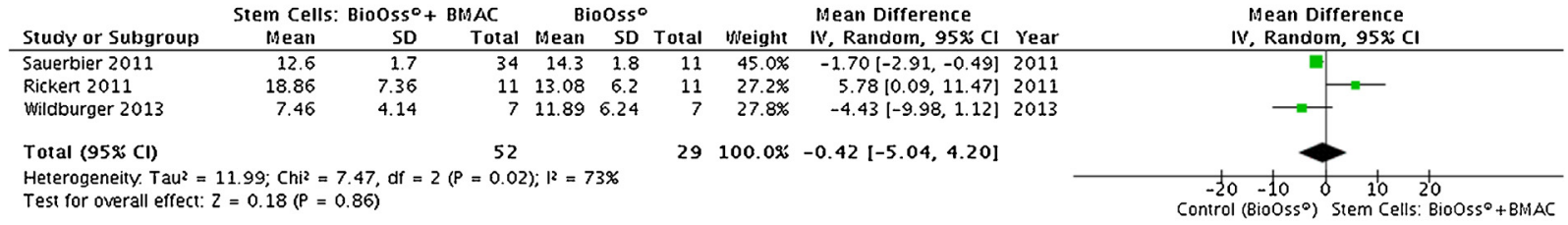

\section{B. New Bone formation (6 months): BioOss@ Vs. Stem Cells (BioOss@+ BMAC system)}

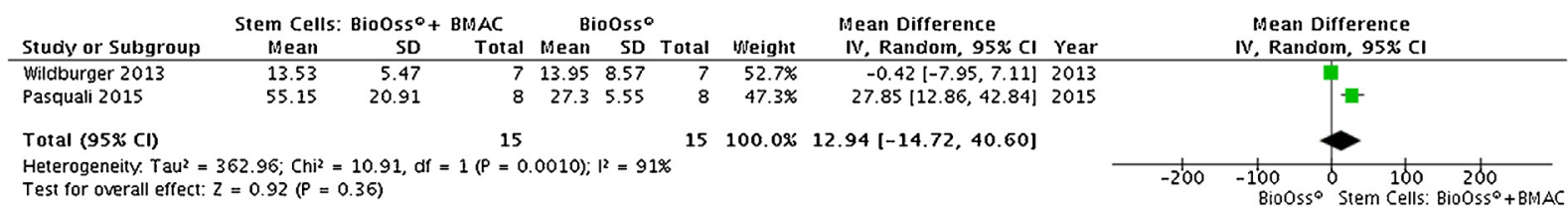

Fig. 7. New bone formation (\%) according to subgroup: Bio-Oss vs. Bio-Oss + BMAC. (A) At 3-4 months. (B) At 6 months.

\section{A. Residual graft content (3-4 months): Stem Cells Vs, Control Grafts}

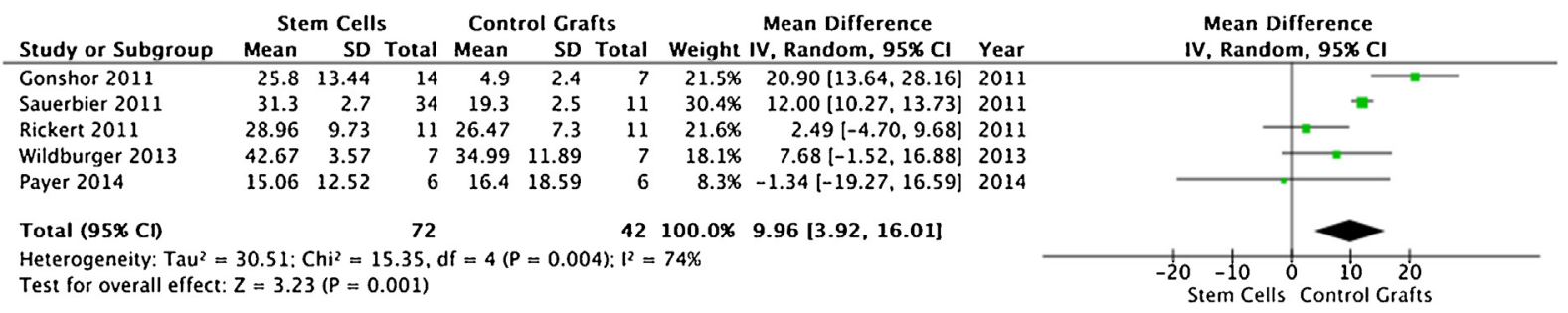

\section{B. Residual graft content (6 months): Stem Cells Vs. Control Grafts}

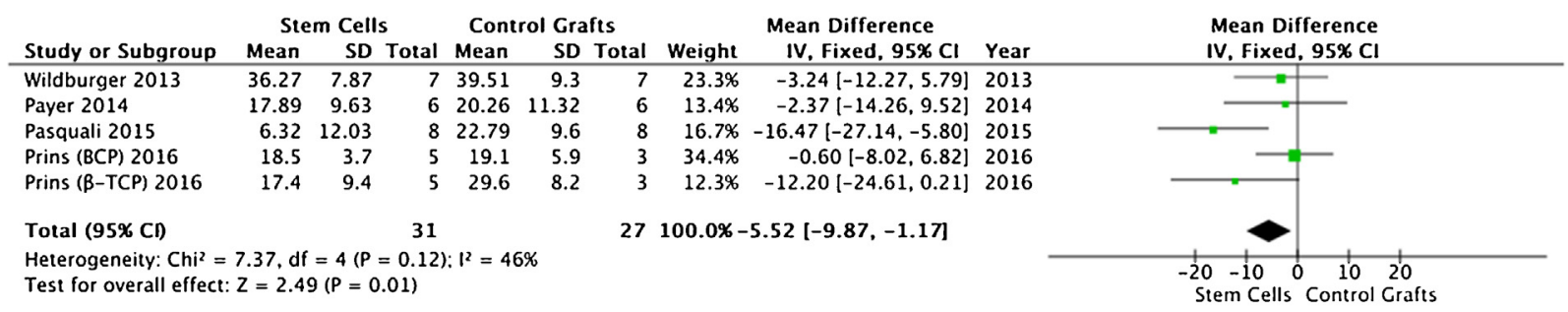

Fig. 8. Overall residual graft content (\%): graft vs. graft + stem cells. (A) At 3-4 months. (B) At 6 months.

the region of atrophic tuberosity, which has osteoprogenitor cells and mature osteoblasts $^{10}$; however, the authors only reported results with regard to marginal bone loss following implant placement. Among the studies analyzed herein, only Gonshor et al. used a commercial allograft prepared from tissue obtained from cadavers within 24 hours after death, reporting important new bone content ${ }^{14}$. In such cases, however, the selective immunodepletion process must be rigorous to avoid rejection of the graft.

Another limitation was the lack of standardization among the studies in terms of the analysis of graft success. It is more feasible and recommendable to analyze success outcomes as a com- plete process with at least 1 year of follow-up. This is to take into consideration not only the histomorphometric and imaging aspects, but also the clinical aspects that involve the implant and its rehabilitation, since the graft must resist the loads that may be presented. In this review, Rickert et al. presented the most complete analysis in terms of success ${ }^{2,8}$. Another problem related to standardization was the absence of information on different conditions (respiratory disease and/or sinusitis) ${ }^{2,8,11,23,25,27-30}$, the inclusion of smokers, since smoking can exert a negative impact on bone regeneration ${ }^{9-}$ $11,14,23-25,27$, and the implant survival rate $^{8}$. Moreover, the small number of patients did not enable more objective conclusions. Thus, the findings may be subject to speculation ${ }^{27,29}$.

Finally, many of the results are highly influenced by the lack of a balance in the sample. For example, in the study by Sauerbier et al., the large difference between the test and control groups was reflected in the weight of the meta-analy$\operatorname{sis}^{28}$. Only the study by Hermund et al. had an acceptable sample size calculation ${ }^{10}$. Kaigler et al. reported that the selection of the sample was based more on viability than statistical precision ${ }^{11}$. However, the greater bone marrow space with Bio-Oss compared to stem cells was conclusive.

Despite difficulties in obtaining clear responses, this article can serve as a starting point for the design of randomized 
A.Residual graft content (3-4 months): BioOss $®$ Vs. Stem Cells (BioOss $®+$ BMAC system)

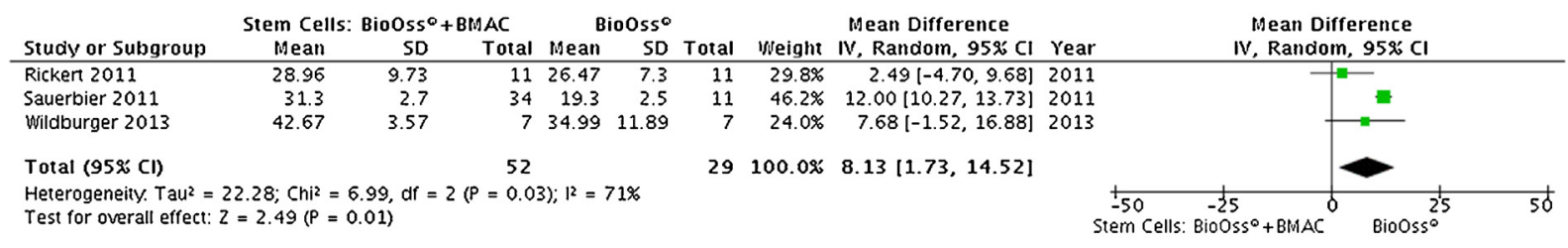

B. Residual graft content (6 months): BioOss ${ }^{2}$ Vs. Stem Cells (BioOss $®+$ BMAC system)

\begin{tabular}{|c|c|c|c|c|c|c|c|c|c|c|c|}
\hline \multirow[b]{2}{*}{ Study or Subgroup } & \multicolumn{3}{|c|}{ Stem Cells: BioOss ${ }^{\circ}+$ BMAC } & \multicolumn{3}{|c|}{ Biooss } & \multicolumn{3}{|c|}{ Mean Difference } & \multirow{2}{*}{\multicolumn{2}{|c|}{$\begin{array}{l}\text { Mean Difference } \\
\text { IV, Fixed, } 95 x \mathrm{CI}\end{array}$}} \\
\hline & Mean & SD & Total & Mean & SD & Total & Wreight & IV, Fiked, 952 Cl & rear & & \\
\hline Wildburger 2013 & 36.27 & 7.87 & 7 & 39.51 & 9.3 & 7 & $58.3 \%$ & $-3.24[-12.27,5.79]$ & 2013 & -5 & \\
\hline Pasquali 2015 & 6.32 & 12.03 & 8 & 22.79 & 9.6 & 8 & $41.7 \%$ & $-16.47[-27.14,-5.80]$ & 2015 & $\rightarrow-7$ & \\
\hline Total (958 Cl) & & & 15 & & & 15 & $100.0 x$ & $-8.76[-15.65,-1.87]$ & & & \\
\hline $\begin{array}{l}\text { Heterogeneity. Chi = } \\
\text { Test for overall effect: }\end{array}$ & $\begin{array}{l}44, d f=1 \\
=2.49(P=\end{array}$ & $\begin{array}{l}0.06) ; \\
01)\end{array}$ & & & & & & & & 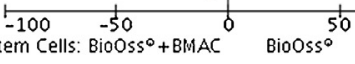 & 100 \\
\hline
\end{tabular}

Fig. 9. Residual graft content (\%) according to subgroup: Bio-Oss vs. Bio-Oss + BMAC. (A) At 3-4 months. (B) At 6 months.

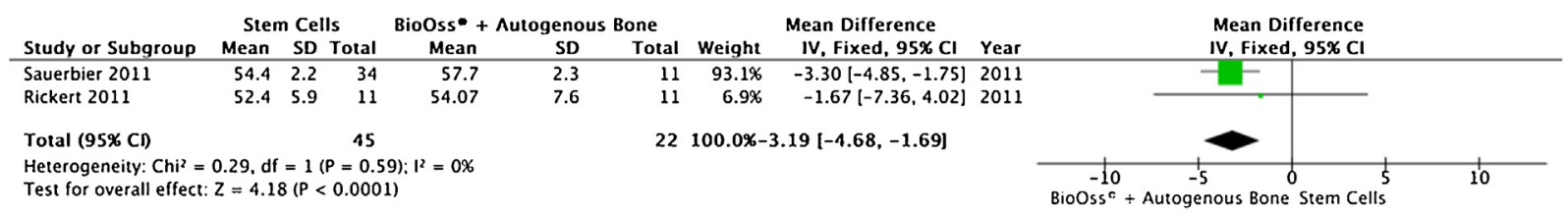

Fig. 10. Bone marrow space (\%): Bio-Oss + autogenous bone vs. Bio-Oss + BMAC.

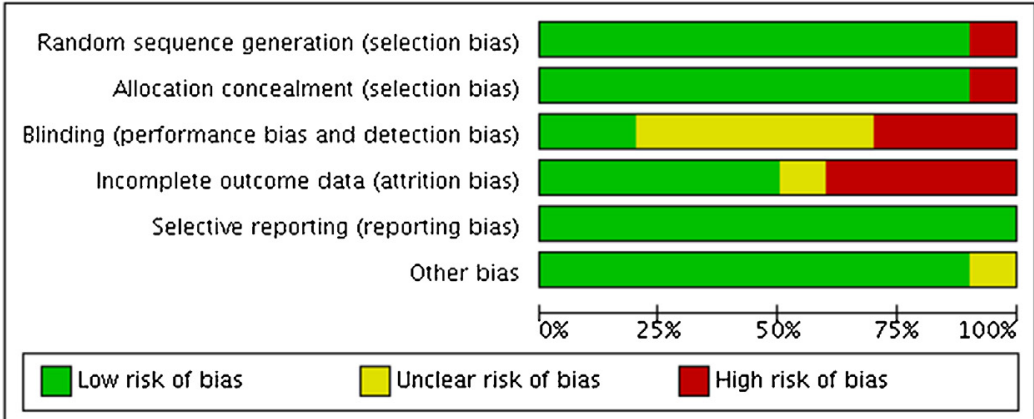

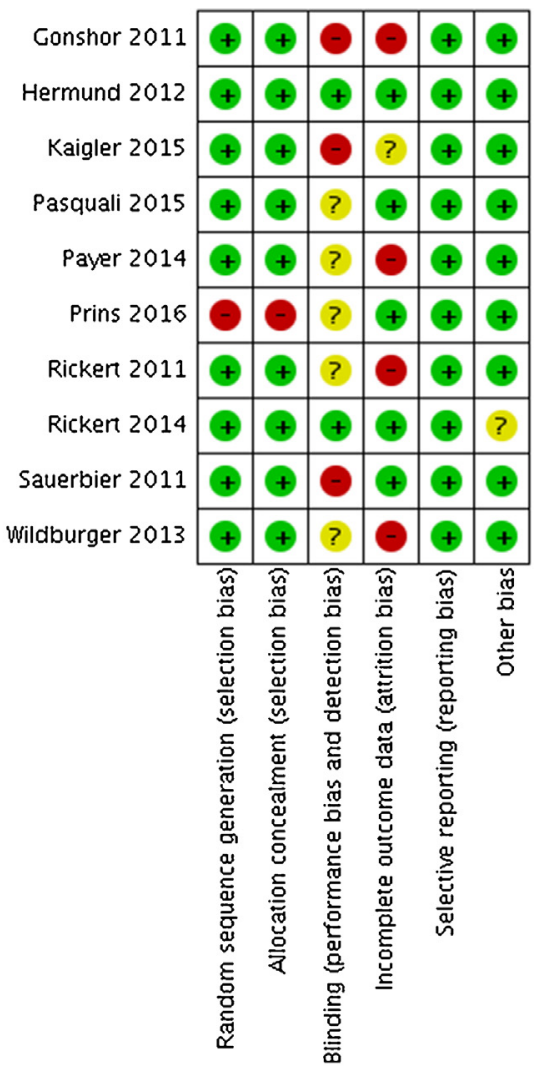

Fig. 11. Risk of bias of the randomized clinical trials. 
clinical trials addressing this and similar topics that could improve the analyses presented. Long-term studies should evaluate the efficacy of stem cells in different steps, taking into consideration clinical, imaging, and histomorphometric aspects. Thus, further randomized clinical trials with better characteristics in terms of the design and a longer follow-up period are needed to draw firm conclusions.

In conclusion, despite the limitations of the present study, the meta-analysis revealed that the inclusion of stem cells did not contribute significantly to improvements in the implant survival rate or the efficacy of bone regeneration.

\section{Funding}

No source of funding.

\section{Competing interests}

No competing interests.

\section{Ethical approval}

Not applicable.

\section{Patient consent}

Not applicable.

Acknowledgements. The authors are grateful to the Brazilian fostering agency Coordenação de Aperfeiçoamento de Pessoal de Nível Superior (CAPES) and Conselho Nacional de Desenvolvimento Científico e Tecnológico (CNPq).

\section{References}

1. Scharager-Lewin D, Arraño-Scharager DP, Biotti-Picand J. Biomaterials in maxillary sinus lift for dental implants. Rev Clin Periodoncia Implantol Rehabil Oral 2017;10:20-5. In Spanish.

2. Rickert D, Sauerbier S, Nagursky H, Menne D, Vissink A, Raghoebar GM. Maxillary sinus floor elevation with bovine bone mineral combined with either autogenous bone or autogenous stem cells: a prospective randomized clinical trial. Clin Oral Implants Res 2011;22:251-8.

3. Mangano FG, Colombo M, Veronesi G, Caprioglio A, Mangano C. Mesenchymal stem cells in maxillary sinus augmentation: a systematic review with meta-analysis. World J Stem Cells 2015;7:976-91.

4. Bertolai R, Catelani C, Aversa A, Rossi A, Giannini D, Bani D. Bone graft and mesenchymal stem cells: clinical observations and histological analysis. Clin Cases Miner Bone Metab 2015;12:183-7.
5. Ceccarelli G, Presta R, Benedetti L, Cusella De Angelis MG, Lupi SM, Rodriguez Y, Baena R. Emerging perspectives in scaffold for tissue engineering in oral surgery. Stem Cells Int 2017;2017:4585401.

6. Park JB. Use of cell-based approaches in maxillary sinus augmentation procedures. $J$ Craniofac Surg 2010;21:557-60.

7. Pasquali PJ, Teixeira ML, Oliveira TA, de Macedo LG, Aloise AC, Pelegrine AA. Maxillary sinus augmentation combining Bio-Oss with the bone marrow aspirate concentrate: a histomorphometric study in humans. Int $J$ Biomater 2015;2015:1-7.

8. Rickert D, Vissink A, Slot WJ, Sauerbier S, Meijer HJ, Raghoebar GM. Maxillary sinus floor elevation surgery with Bio-Oss mixed with a bone marrow concentrate or autogenous bone: test of principle on implant survival and clinical performance. Int J Oral Maxillofac Surg 2014;43:243-7.

9. Shayesteh YS, Khojasteh A, Soleimani M, Alikhasi M, Khoshzaban A, Ahmadbeigi N. Sinus augmentation using human mesenchymal stem cells loaded into a beta-tricalcium phosphate/hydroxyapatite scaffold. Oral Surg Oral Med Oral Pathol Oral Radiol Endod 2008;106:203-9.

10. Hermund NU, Donatsky O, Nielsen H, Clausen C, Holmstrup P. Long-term changes in graft height after sinus floor augmentation with mesenchymal stem cells in a randomised clinical trial: radiographic evaluation with a minimum follow up of 2.5 years. $J$ Dent Med Med Sci 2012;2:5-14.

11. Kaigler D, Avila-Ortiz G, Travan S, Taut AD, Padial-Molina M, Rudek I, Wang F, Lanis A, Giannobile WV. Bone engineering of maxillary sinus bone deficiencies using enriched CD90+ stem cell therapy: a randomized clinical trial. J Bone Miner Res 2015;30:1206-16.

12. Smiler D, Soltan M, Lee JW. A histomorphogenic analysis of bone grafts augmented with adult stem cells. Implant Dent 2007; 16:42-53.

13. McAllister BS, Haghighat K, Gonshor A. Histologic evaluation of a stem cell-based sinus-augmentation procedure. J Periodontol 2009;80:679-86.

14. Gonshor A, McAllister BS, Wallace SS, Prasad H. Histologic and histomorphometric evaluation of an allograft stem cell-based matrix sinus augmentation procedure. Int $J$ Oral Maxillofac Implants 2011;26:1231310.

15. Cristalli MP, Marini R. Performance of mesenchymal cell-scaffold constructs in human oral reconstructive surgery: a systematic review. J Biotechnol Biomater 2016;6:1-9.

16. Higgins J, Green S. Cochrane handbook for systematic reviews of interventions version 5.1.0. The Cochrane Collaboration; 2011.

17. Shamseer L, Moher D, Clarke M, Ghersi D, Liberati A, Petticrew M, Shekelle P, Stewart LA, PRISMA-P Group. Preferred reporting items for systematic review and meta-analy- sis protocols (PRISMA-P) 2015: elaboration and explanation. BMJ 2015;350:g7647.

18. Landis JR, Koch GG. The measurement of observer agreement for categorical data. Biometrics 1977;33:159-74.

19. Carvalho A, Silva V, Grande A. Avaliação do risco de viés de ensaios clínicos randomizados pela ferramenta da colaboração Cochrane. Diagn Tratamento 2013;18:38-44.

20. Chrcanovic BR, Albrektsson T, Wennerberg A. Immediately loaded non-submerged versus delayed loaded submerged dental implants: a meta-analysis. Int J Oral Maxillofac Surg 2015;44:493-506.

21. Duttenhoefer F, Hieber SF, Stricker A, Schmelzeisen R, Gutwald R, Sauerbier S. Follow-up of implant survival comparing Ficoll and bone marrow aspirate concentrate methods for hard tissue regeneration with mesenchymal stem cells in humans. Biores Open Access 2014;3:75-6.

22. Ueda M, Yamada Y, Ozawa R, Okazaki Y. Clinical case reports of injectable tissue-engineered bone for alveolar augmentation with simultaneous implant placement. Int J Periodontics Restorative Dent 2005;25:129-37.

23. Yamada Y, Nakamura S, Ito K, Kohgo T, Hibi H, Nagasaka T, Ueda M. Injectable tissue-engineered bone using autogenous bone marrow-derived stromal cells for maxillary sinus augmentation: clinical application report from a 2-6-year follow-up. Tissue Eng Part A 2008;14:1699-707.

24. Ueda M, Yamada Y, Kagami H, Hibi H. Injectable bone applied for ridge augmentation and dental implant placement: human progress study. Implant Dent 2008;17:8290.

25. Yamada Y, Nakamura S, Ueda M, Ito K. Osteotome technique with injectable tissue-engineered bone and simultaneous implant placement by cell therapy. Clin Oral Implants Res 2013;24:468-74.

26. Hibi H, Yamada Y, Ueda M, Schmelzeisen R. Tissue-engineered osteogenic materials for dental implants: clinical results from Germany and Japan. Int Med J 2005;12:243-5.

27. Wildburger A, Payer M, Jakse N, Strunk D, Etchard-Liechtenstein N, Sauerbier S. Impact of autogenous concentrated bone marrow aspirate on bone regeneration after sinus floor augmentation with a bovine bone substitute-a split-mouth pilot study. Clin Oral Implants Res 2014;25:1175-81.

28. Sauerbier S, Rickert D, Gutwald R, Nagursky H, Oshima T, Xavier SP, Christmann J, Kurz P, Menne D, Vissink A, Raghoebar G, Schmelzeisen R, Wagner W, Koch FP. Bone marrow concentrate and bovine bone mineral for sinus floor augmentation: a controlled, randomized, singleblinded clinical and histological trial-perprotocol analysis. Tissue Eng Part A 2011;17:2187-97.

29. Payer M, Lohberger B, Strunk D, Reich KM, Acham S, Jakse N. Effects of directly autotransplanted tibial bone marrow aspirates on 
12 Niño-Sandoval et al.

bone regeneration and osseointegration of dental implants. Clin Oral Implants Res 2014;25:468-74.

30. Prins HJ, Schulten EA, Ten Bruggenkate CM, Klein-Nulend J, Helder MN. Bone regeneration using the freshly isolated autologous stromal vascular fraction of adipose tissue in combination with calcium phosphate ceramics. Stem Cells Transl Med 2016;5:1362-74.

31. Viña JA, El-Alami M, Gambini J, Borras C, Viña J, Peñarrocha MA. Application of mesenchymal stem cells in bone regenerative procedures in oral implantology. A literature review. J Clin Exp Dent 2014;6:e60-5.
32. Starch-Jensen T, Aludden H, Hallman M, Dahlin C, Christensen AE, Mordenfeld A. A systematic review and meta-analysis of long-term studies (five or more years) assessing maxillary sinus floor augmentation. Int $J$ Oral Maxillofac Surg 2018;47:103-16.

33. Jensen T, Schou S, Stavropoulos A, Terheyden H, Holmstrup P. Maxillary sinus floor augmentation with Bio-Oss or Bio-Oss mixed with autogenous bone as graft: a systematic review. Clin Oral Implants Res 2012;23:263-73.
Address:

Belmiro Cavalcanti do Egito Vasconcelos

Department of Oral and Maxillofacial Surgery

University of Pernambuco - School of

Dentistry (UPE/FOP)

Av. General Newton Cavalcanti

1650 - Tabatinga

Camaragibe

CEP 54.756-220

Pernambuco

Brazil

E-mail: belmiro.vasconcelos@upe.br 